\title{
Analysis of Power Generation and Transmission from Very Large-Scale Photovoltaic Systems in Algeria
}

\author{
S. Flazi ${ }^{1}$, A. Boudghene Stambouli ${ }^{2}$ and M. Bouzid ${ }^{1}$ \\ ${ }^{1}$ Department of Electrical Engineering, ${ }^{2}$ Department of Electronics \\ Electrical and Electronics Engineering Faculty \\ University of Sciences and Technology of Oran Mohamed Boudiaf (USTO-MB) \\ BP 1505, EL M’Naouer, Oran (31000), Algeria. \\ E-mail: flazis@yahoo.fr
}

\begin{abstract}
In addition to the well-recognised two values of vast land and sunshine of Algeria, its Sahara desert has the third value, energy production and export. Subsequently, Algeria can then become a role model to other countries in the world that has huge solar and energy feedstock. In this article, a particular attention is being given to the Algerian Sahara in terms of solar potential capability in that it could capture enough solar energy to meet the total energy needs for sustainable development of Algeria, Sahara cultivation and Repopulation and electricity Export to Europe using Very Large ScalePhotovoltaic (VLS-PV) system. Moreover, the article is also concerned with studying the energy transmission losses from the generation site, in depth Sahara of the south of the country, to the north as well to European countries.

A rough calculation of the Losses was made for a transmission overhead line of $400 \mathrm{kV}$ three-phases, 1000 MVA using ALMELEC cable of $1600 \mathrm{~mm}^{2}$. The calculated losses results were found to be $15 \%$ per 1000 $\mathrm{km}$. The optimal location to start the installation of VLSPV systems is proposed.
\end{abstract}

\section{Keywords}

Photovoltaic, Solar energy, Sustainable development, Sahara, Transmission losses

\section{Introduction}

At the end of oil and gas era, there will be sun, sand and free area at the Algerian Sahara, sufficient to meet the total energy needs for sustainable development of Algeria, Sahara cultivation \& Repopulation and electricity Export to Europe. To prove that we calculate, at first, the area of Algeria desert suitable for the installation of VLS-PV system followed by a rough calculation of photovoltaic (PV) capacity and annual power generation for all the proposed area. A comparison with world primary energy consumption [1] allowed us to conclude that Algeria solar net annual energy potential using VLS-PV is more than the half of world energy consumption in the horizon of 2030, meaning that the solar energy potential of Algerian Sahara is sufficient for the above mentioned needs. However, the problem is not in the energy potential, as it is the case of some others countries, or in energy production, it is essential in the assessment of transmission losses of very large power of several GW and for a very long distance up to $2000 \mathrm{~km}$ !

Algeria population is concentrated in the north, near the Mediterranean Sea, Sahara desert of Algeria, 86\% of the whole area, is mostly empty and receives about as much reliable sunlight as you could possibly hope for. Therefore, most of the electrical energy is mainly needed for the north of the country. In this case, transmission losses may be a barrier to Sahara solar energy exploitation. It is then, very important, in view of energy strategy, to analyses the gains and losses of energy generation in the depth of Sahara. May be, it is better to find the optimal position of VLS-PV system in the Sahara.

\section{Algeria Desert Irradiation}

Total annual irradiation for all world deserts (31 deserts of 19 million $\mathrm{km}^{2}$ ), was calculated [2-4]. A summary of calculated results is depicted in Table 1 . It can be seen easily that Algeria desert has an $11.4 \%$ share of the total irradiation of world deserts. The annual Algerian desert irradiation (395600 Mtoe/y) is more than 26 times higher than the primary energy consumption of the world in 2030 (15000 Mtoe) [1].

\section{Algeria desert solar net energy potential using VLS-PV}

\subsection{Suitable area for VLS-PV system}

The deserts offer contrasting landscapes: sand dunes, oasis, wades (dry beds of rivers and streams), mountains, reg (composed of pebbles and gravel) and steppes. It is 
impossible to use the total area of the deserts for VLS-PV system; the suitable area for this kind of systems is the regs and the steppes only. Table 2 shows a rough calculation of the different areas of Algeria desert; it can be seen that the suitable area for VLS-PV is about $1200000 \mathrm{~km}^{2}$.

\subsection{The range of $V L S-P V$ system}

The size of a Very Large Scale- Photovoltaic system may range from $10 \mathrm{MW}$ to 1 or several GW, consisting of one plant, or an aggregation of plural units [5]. Figure 1 shows a conceptual image of a one GW system [5,6 ], it occupied
$30 \mathrm{~km}^{2}$ (15 km x $2 \mathrm{~km}$ ) of land, taking into account, PV collectors, buffer plant, roods and transmission lines.

\subsection{PV capacity and annual power generation}

Table 3 shows a rough calculation of PV capacity and annual power generation for all the suitable area of Algeria desert using VLS-PV based on a conceptual image of a one GW system of figure 1. A comparison with world primary energy consumption [1] allowed us to conclude that Algeria solar net annual energy potential using VLS-PV without buffer plants (8100 Mtoe) is more than the half of world consumption in 2030 (15000 Mtoe).

Table 1: Algeria desert irradiation compared to world energies

\begin{tabular}{|l|l|l|l|l|l|}
\hline $\begin{array}{l}\text { WORLD REGION } \\
\text { DESERTS }\end{array}$ & $\begin{array}{l}\text { Area } \\
\left(\mathrm{km}^{2}\right)\end{array}$ & $\begin{array}{l}\text { Annual irradiation } \\
\left(\mathrm{kWh} / \mathbf{m}^{2}\right)\end{array}$ & $\begin{array}{l}\text { Total annual } \\
\text { irradiation (PWh) }\end{array}$ & $\begin{array}{l}\text { Total annual } \\
\text { irradiation (Mtoe) }\end{array}$ & $\begin{array}{l}\text { Share of total annual } \\
\text { irradiation (\%) }\end{array}$ \\
\hline $\begin{array}{l}\text { TOTAL WORLD } \\
\text { DESERTS (31 deserts) }\end{array}$ & 18978143 & 2136 & 40537 & 3486218 & 100 \\
\hline North Africa (NA) & 8600000 & 2300 & 19780 & 1701080 & 49 \\
\hline Middle East (ME) & 3052400 & 2137 & 6524 & 561052 & 16 \\
\hline Algerie & 2000000 & 2300 & 4600 & 395600 & 11,4 \\
\hline
\end{tabular}

Table 2: different areas of Algeria desert

\begin{tabular}{|l|l|l|l|l|}
\hline $\begin{array}{l}\text { Total area } \\
\left(\mathbf{k m}^{2}\right)\end{array}$ & $\begin{array}{l}\text { Sand dune area } \\
\left(\mathrm{km}^{2}\right) 20 \%\end{array}$ & $\begin{array}{l}\text { Oasis area } \\
\left(\mathrm{km}^{2}\right)\end{array}$ & $\begin{array}{l}\text { Mountain area } \\
\left(\mathrm{km}^{2}\right) \mathbf{1 8 \%}\end{array}$ & $\begin{array}{l}\text { Reg and Steppe } \\
\text { area }\left(\mathbf{k m}^{2}\right)\end{array}$ \\
\hline 2000000 & 400000 & 40000 & 360000 & 1200000 \\
\hline
\end{tabular}

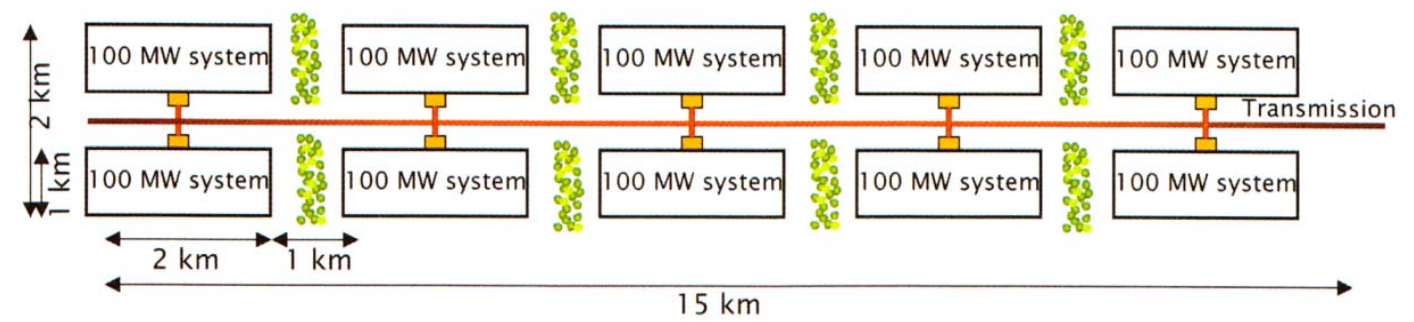

Fig 1. A conceptual image of a one GW $[5,6]$

Table 3: PV capacity and Annual energy generation

for all the Suitable Deserts area of Algeria

\begin{tabular}{|l|l|l|l|l|}
\hline $\begin{array}{l}\text { PV Capacity and Energy } \\
\text { generation using VLS-PV } \\
\text { system }\end{array}$ & $\begin{array}{l}\text { PV } \\
\text { capacity } \\
\text { (TW) }\end{array}$ & $\begin{array}{l}\text { Annual } \\
\text { generation } \\
\text { (PWh) }\end{array}$ & $\begin{array}{l}\text { Annual } \\
\text { generation } \\
\text { (Mtoe) }\end{array}$ & $\begin{array}{l}\text { Annual } \\
\text { generation to } \\
\text { gross annual } \\
\text { irradiation \% }\end{array}$ \\
\hline Without buffer plant & 60 & 95 & 8100 & 2,1 \\
\hline With buffer plant & 40 & 63 & 5500 & 1,4 \\
\hline
\end{tabular}




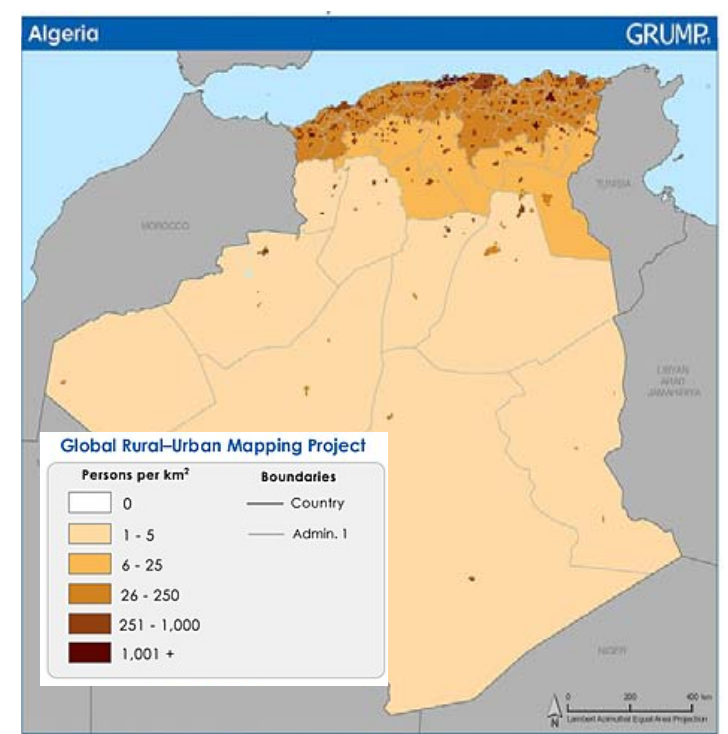

Fig 2. Population density of Algeria

\section{Algeria Population and Irradiation Distribution}

As show in Figure 2, the population density of Algeria [7]; is mainly concentrated in the north, near the Mediterranean sea, while in the Sahara, with $86 \%$ of Algeria's land, the density is very small and solar feedstock highest, as presented on figure 3 [8]. The importance of access to clean energy from the south, having free land and huge energy potential cannot be overstated. In this case transmission losses may be a barrier to Sahara solar energy exploitation.

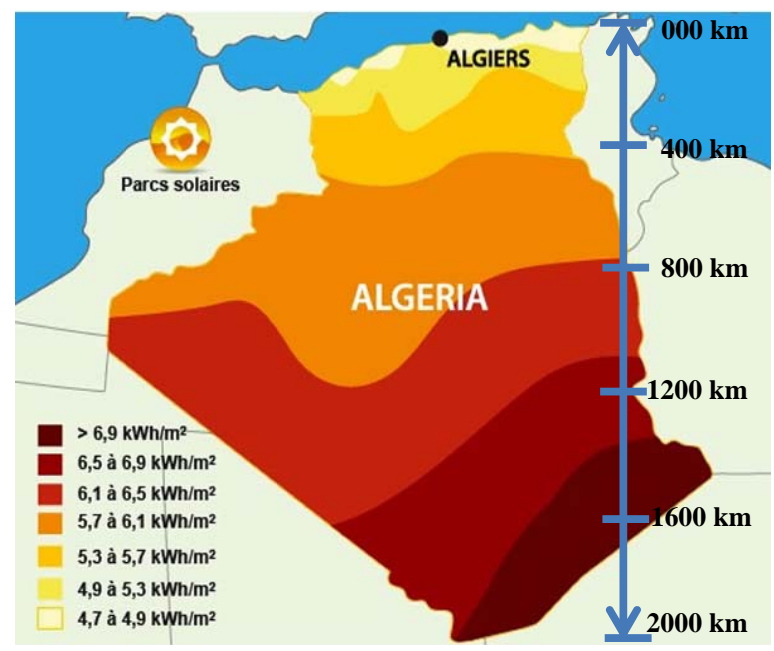

Figure 3: In the left of the figure: Annual average of global irradiation received on a horizontal surface.

In the right of the figure: Distance from the sea.

A rough calculation of the losses was made for a transmission overhead line of $400 \mathrm{kV}$ three-phases, 1000 MVA using ALMELEC cable of $1600 \mathrm{~mm}^{2}$. The calculated losses rate were $15 \%$ per $1000 \mathrm{~km}$. Table 4 shows the decrease in energy according to the transmission distance. The red numbers are the irradiation to the different distances from the sea, and the blacks ones are the calculated values at arrival to different distance.

For a distance from the sea equal to $1800 \mathrm{~km}$ the naturel irradiation is $7100 \mathrm{Wh} / \mathrm{m} 2 /$ day, after $400 \mathrm{~km}$ it become $6674 \mathrm{Wh} / \mathrm{m} 2 /$ day, at $1000 \mathrm{~km}$ from the sea it become $6248 \mathrm{Wh} / \mathrm{m} 2 /$ day and at $100 \mathrm{~km}$ from the sea it becomes $5290 \mathrm{Wh} / \mathrm{m} 2 /$ day.

Table 4 the decrease in energy according to the transmission distance

\begin{tabular}{|c|c|c|c|c|c|c|c|c|}
\hline & $\begin{array}{c}\text { Annual average of } \\
\text { global irradiation } \\
(\mathrm{Wh} / \mathrm{m} 2 / \mathrm{d})\end{array}$ & $\begin{array}{c}\text { Distance from } \\
\text { the sea }(\mathrm{km})\end{array}$ & \multicolumn{6}{|l|}{$\begin{array}{l}\text { Losses for three-phase } 400 \mathrm{kV}, 1000 \mathrm{MVA}, \\
\text { Almelec cable of } 1600 \mathrm{~mm} 2 .\end{array}$} \\
Losses = $15 \%$ per $1000 \mathrm{~km}$. \\
\hline 1 & 5100 & 100 & 5290 & 5394 & 5450 & 5458 & 5335 & 5100 \\
\hline 2 & 5500 & 300 & 5503 & 5595 & 5639 & 5635 & 5500 & \\
\hline 3 & 5900 & 600 & 5822 & 5896 & 5922 & 5900 & & \\
\hline 4 & 6300 & 1000 & 6248 & 6298 & 6300 & & & \\
\hline 5 & 6700 & 1400 & 6674 & 6700 & & & & \\
\hline 6 & 7100 & 1800 & 7100 & & & & & \\
\hline
\end{tabular}

\section{Discussion and conclusion}

The calculation results of Table 4 show that the gain in the production of electrical energy using VLS-PV systems in the depth of Sahara, will be lost in the transmission lines from Sahara south to the north. In this case, the investment in the construction of transmission lines will be lost completely.

The optimal location to start the installation of VLS-PV systems is in the north of the Sahara, in the orange area, having an energy ranging between 5.3 and $5.7 \mathrm{kWh} / \mathrm{m}^{2}$. After that we can extend toward the south gradually, waiting may be for the introduction of superconducting cables in the energy transport means! This created and proposed energy system dynamics model, in Algeria's Sahara, can be implemented in other countries, such as the ones of the Maghreb region, and the results can be compared with the current work performed in Algeria. 


\section{References:}

[1] BP Statistical Review of world Energy, June 2012.

[2] S. Flazi, A. Boudghene Stambouli and Z. Khiat "Sahara solar potentials: energetic, socio-economic and sand reserve" 2AASE Forum and 4SSB Workshop - 15 and 16 May 2012 - USTO / ORAN

[3] S. Flazi, A. Boudghene Stambouli and Z. Khiat, "The potentials of Arabic Middle East deserts: energetic and socio-economic” GCREEDER 2013, September 10th 12th 2013, Amman-Jordan

[4] S. Flazi, A. Boudghene Stambouli and Z. Khiat, "Sahara photovoltaic potential and silicon reserve"
3AASEF \& 5SSBWS - 6 and 8 May 2013 - Hirosaki Japan

[5] Energy from the desert, Very Large Scale PhotoVoltaic systems, earthscan publishing for a sustainable future, London Sterling, VA, 2006.

[6] Energy from the desert, Feasibility of Very Large Scale Photovoltaice Power Generation Systeme. James \& James 2003

[7] Atlas solair Algerien, Centre de Développement des Energies Renouvelables "CDER” 2014 Sourc http://www.mediwatt.com/business-parcs-solairesgisement-solaire.php.

[8] NASA, Maps » Population Density Grid, v1, http://sedac.ciesin.columbia.edu/data/set/grump-v1population-density/maps?facets=region:africa 